\title{
The critical role of relationship in education
}

\begin{tabular}{|c|c|}
\hline \multicolumn{2}{|c|}{$\begin{array}{l}\text { Author: } \\
\text { Francois Wessels }{ }^{1,2}\end{array}$} \\
\hline \multicolumn{2}{|c|}{$\begin{array}{l}\text { Affiliations: } \\
{ }^{1} \text { Life Coach and Narrative } \\
\text { Practitioner, Coaches and } \\
\text { mentors of South Africa } \\
\text { (COMENSA), South Africa }\end{array}$} \\
\hline \multicolumn{2}{|c|}{$\begin{array}{l}{ }^{2} \text { Department of Practical } \\
\text { Theology, Faculty of } \\
\text { Theology, University of } \\
\text { Pretoria, South Africa }\end{array}$} \\
\hline \multicolumn{2}{|c|}{$\begin{array}{l}\text { Note: } \\
\text { Dr Francois Wessels is a } \\
\text { research associate in the } \\
\text { Department of Practical } \\
\text { Theology, at the Faculty } \\
\text { of Theology, University of } \\
\text { Pretoria, South Africa. }\end{array}$} \\
\hline \multicolumn{2}{|c|}{$\begin{array}{l}\text { Correspondence to: } \\
\text { Francois Wessels }\end{array}$} \\
\hline \multicolumn{2}{|c|}{$\begin{array}{l}\text { Email: } \\
\text { francois@francoiswessels. } \\
\text { co.za }\end{array}$} \\
\hline \multicolumn{2}{|c|}{$\begin{array}{l}\text { Postal address: } \\
\text { PO Box 25521, Monun } \\
\text { Park, Pretoria 0105, } \\
\text { South Africa }\end{array}$} \\
\hline \multicolumn{2}{|c|}{$\begin{array}{l}\text { Dates: } \\
\text { Received: } 25 \text { Apr. } 2014 \\
\text { Accepted: } 08 \text { July } 2014 \\
\text { Published: } 28 \text { Sept. } 2015\end{array}$} \\
\hline \multicolumn{2}{|c|}{$\begin{array}{l}\text { How to cite this article: } \\
\text { Wessels, F., 2015, 'The } \\
\text { critical role of relationship } \\
\text { education', HTS Teologiese } \\
\text { Studies/Theological Studies } \\
71(3), \text { Art. \#2702, } 8 \text { pages. } \\
\text { http://dx.doi.org/10.4102/ } \\
\text { hts.v71i3.2702 }\end{array}$} \\
\hline \multicolumn{2}{|c|}{$\begin{array}{l}\text { Copyright: } \\
\text { (C) 2015. The Authors. } \\
\text { Licensee: AOSIS } \\
\text { OpenJournals. This work is } \\
\text { licensed under the Creative } \\
\text { Commons Attribution } \\
\text { License. }\end{array}$} \\
\hline \multicolumn{2}{|l|}{ Read online: } \\
\hline 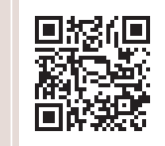 & $\begin{array}{l}\text { Scan this QR } \\
\text { code with your } \\
\text { smart phone or } \\
\text { mobile device } \\
\text { to read online. }\end{array}$ \\
\hline
\end{tabular}

A TED talk by Susan Savage-Rumbaugh entitled 'The gentle genius of the bonobos' tells the story of the learning ability of these gentle primates. Although these animals were never deliberately taught any skills - cognitive, linguistic or technical - they managed to learn a vast amount from the scientists in the program by just observing, experimenting and imitating them. And the key to this learning process was the significance these humans had in the lives of the bonobos. The relationship between the scientists and the bonobos was therefore key to the learning experience and the learning process. This reminded me of the success stories I have witnessed within our therapist training program at the counselling centre where I have been lecturing. We used to train pastoral therapists within the narrative paradigm. Within this paradigm, reality is considered to be socially constructed, thus emphasising the relational nature of identity, agency and knowledge. Aligning the 'teaching methodology' with this epistemology invariably requires a participatory approach to training, which in our context led to the adoption of seminars rather than lectures, and a conversational style of learning (with the lecturer - or more aptly, the facilitator - becoming a co-learner!). This article will now explore what the effect of relationship building as a deliberate prerequisite for learning might be on learner agency.

'The teacher who is indeed wise does not bid you to enter the house of his wisdom but rather leads you to the threshold of your mind.' (Khalil Gibran)

\section{Introduction}

\section{Khalil Gibran so famously said:}

Work is love made visible. And if you cannot work with love but only with distaste, it is better that you should leave your work and sit at the gate of the temple and take alms of those who work with joy.

In this article the critical role of relationship in education and training will be discussed. Humans will be described as relational beings and it will be pointed out that relationship is essential to meaning-making. Once meaning-making has been linked to learning, we can proceed to suggest that relationship is critical to learning, teaching and education. Some ways of building relationships will be discussed along the way.

A TED talk by Susan Savage-Rumbaugh (2004) entitled 'The gentle genius of the bonobos' tells the story of the learning ability of these gentle primates. Although these animals were never deliberately taught any skills - cognitive, linguistic or technical - they managed to learn a vast amount from the scientists in the program by just observing, experimenting and imitating them. And the key to this learning process was the significance these humans had in the lives of the bonobos. The relationship between the scientists and the bonobos was therefore key to the learning experience and the learning process. This reminded me of the success stories I have witnessed within our therapist training program at the counselling centre where I had been working at the time this article was written. We have been training pastoral therapists within the narrative paradigm. Within this paradigm, reality is considered to be socially or, as I prefer to think about it, relationally constructed, thus emphasising the relational nature of identity, agency and knowledge. Aligning the 'teaching methodology' with this epistemology invariably requires a participatory approach to training, which in our context led to the adoption of seminars rather than lectures, and a conversational style of learning (with the lecturer - or more aptly, the facilitator - becoming a co-learner!). This article will now explore what the effect of relationship building as a deliberate prerequisite for learning might be on learner agency (Wessels 2014).

\section{Humans as relational beings}

'Humans are tuned for relationship. The eyes, the skin, the tongue, ears, and nostrils - all are gates where our body receives the nourishment of otherness' - David Abram (1997:ix). 
'Relationship precedes identity' - Jonathan Sacks.

Stanley Grentz (2006) suggests that personhood is 'bound up with relationality'. Speaking from a Christian theological perspective, he then proceeds to suggest that the fullness of relationality lies 'ultimately in relationship with the triune God'. Earlier he posits that our selves emerge within the 'dialogue between the " $\mathrm{I}$ " and the social context'; the self thus becomes an on-going process 'rather than ... a given which exists prior to social relationships', forming a narrative with both past and future perspectives.

Sacks (2000:57-58) describes the story of the creation of the world in the book of Genesis, indicating how everything which was created was described as good ... up to the surprising, perhaps shocking remark that God looked upon something and judged that not to be good. And that state which God perceived not to be good, was Adam's state of being alone: 'And the LORD God said, it is not good that the man should be alone; I will make him a help meet for him' (Gn 2:18).

Sacks proceeds to remark on two propositions which he suggests will frame the Bible's entire framework of mankind. The first he proposes affirms the sanctity of the human individual as an individual created in the image of God. The second proposition he considers to be assertive of the incompleteness of the individual as individual ('it is not good that the man should be alone'). From this, Sacks suggests, the human need for relationship is derived. Later on he suggests that relationship precedes identity (Sacks 2000:61).

Discussing identity from a spiritual perspective, Thomas Moore (1994:105) suggests that identity is not a solitary achievement, but a communal experience, always implying a relationship to others'. Elsewhere (1994:79) he refers to a paradoxical relationship between community and selfhood, indicating that 'community can exist only where people are free to be individuals'.

In the prologue to his book Relational being: Beyond self and community, Gergen (2009) supports this view as he proposes an account of human action which replaces the presumption of bounded selves (or an internal state of understanding identity - see how Carey and Russell (2003) describe this concept which was introduced by Michael White) with 'a vision of relationship', which he describes as a process which 'precedes the very concept of self'. He continues to suggest that 'virtually all intelligible action is born, sustained and/or extinguished within the on-going process of relationship'. It follows that there can be no isolated self or fully private experience. This reminds of the sentiments expressed by the Irish poet and philosopher David Whyte in his 2011-discussion of the conversational nature of reality in which he points to all life forms always being in relationship or as he refers to it, 'in conversation'.

Gergen (2009) posits that we exist in a 'world of coconstitution', always 'already emerging from relationship outside of which we cannot step'. He boldly states that 'the future well-being of the planet depends significantly on the extent to which we can nourish and protect not individuals, or even groups, but the generative processes of relating'.

Wessels (2010) discusses relationship in the process of meaning-making and indicates that relationship forms an integral part in our experience of a life that matters. According to him, experience of a meaningful life is enhanced by social involvement. Social involvement in this context refers to having significant relationships with other people (interpersonal orientation) and to serving others (altruism or a service orientation).

\section{Learning as meaning-making}

Veteran educator James Comer (2005) states that, ' $[n]_{0}$ significant learning occurs without a significant relationship'.

In this article I shall adopt a social constructionist - or as I prefer to think of it - a relational constructionist epistemology. This implies that we assume that meaning is generated in the relationships we form and maintain. Relationship here is used in a very generic sense of the word, referring both to our social position with other people as well as to social structures and discourses.

When using the word 'discourse', I am referring to all those taken for granted 'truths' which we have accepted and dare not even question for the fear of starting the unravelling of the fabric of our coherent existential securities - in our thinking one thread becoming undone may just lead to the next and the next one. These discourses are potential areas of meaning to be explored by means of deconstruction processes. In this sense, we may have to consider how deconstruction can be employed to explore different understandings of these discourses without removing all our securities. Learning discourses need to be explored and learning needs to be discussed as a risky transformational process.

Ignelzi (2000:5) posits that ' $[m]$ eaning-making, the process of how individuals make sense of knowledge, experience, relationships, and the self, must be considered in designing college curricular environments supportive of learning and development'. This indicates that meaning-making should be considered as central to the educational or learning process. He then proceeds to discuss how humans experience and learn, suggesting that principles are characteristic of these processes, namely that:

- Humans actively construct their own realities. This is built on the assumption that what an organism does, is organise, and what human organisms organise, is meaning.

- Meaning-making develops over time and experience. Quoting Kegan (1982, 1994), Ignelzi suggests that this meaningmaking process continues throughout one's life span.

- The process of learning and teaching is strongly influenced by the ways participants make meaning. New experiences and learning are interpreted through our current constructions of reality, these becoming filters to what we 
consider to be meaningful, almost like the light filters on a camera only allowing certain frequencies of light to pass through. Thus, when we are presented with information that doesn't fit our meaning-making, we may discount or ignore it. According to Ignelzi (2000:6): '[E]ducation isn't simply presenting more adequate information in an effective manner; it is a process that must incorporate the developmental readiness of the student ... and must construct a developmental "bridge" between the student's current way of understanding and the new way, thus providing a path on which to cross over'.

Kegan (1982:11) is quoted by Ignelzi (2000), suggesting that

$[t]$ he activity of being a person is the activity of meaning-making. There is no feeling, no experience, no thought, no perception, independent of a meaning-making context in which it becomes a feeling, an experience, a thought, a perception, because we are the meaning-making context. (p. 7)

This will then include the learning process, and we may think of learning as meaning-making process.

Courtenay, Merriam and Reeves (1998) report that 'at the heart of transformational learning is meaning-making - the act of "making sense" of an experience'.

\section{Relationship: The foundation for education and training}

George Washington Carver says all learning is understanding relationships.

Yet, the value of relationships is often downplayed or ignored completely in teacher preparation programs. Even more disturbing is the lack of useable information on the relationship building process. (Pierson 2005)

Once again, reminding ourselves of the narrative paradigm: According to Bruner (1990), events from the set of activities or 'landscape of action' are interpreted - I often think of this process as passing experiences over a hermeneutical bridge to derive the inherent meanings, hopes, dreams or intentions which in turn become part of the meaning dimension or identity plane he called the 'landscape of consciousness' or which we can call the 'landscape of meaning'. We can therefore think of human beings to be interpreting beings, or homo sapiens as homo hermeneuticus (see Bruner 1986:7 in this regard). According to Bruner (1986:7): 'Every telling is an arbitrary imposition of meaning on the flow of memory, in that we highlight some causes and discount others; that is, every telling is interpretive'. This hermeneutical process can be understood to be a meaning-making process.

In this article, it has been indicated that we are meaningmakers - that we can refer to human beings as homo hermeneuticus, or the interpreting man.

Furthermore, this process of making meaning of action and experience is relational. Our relational space or the relationships within which we find ourselves, are therefore integral to our meaning-making. Next, it has been described how education or training and learning are meaning=making processes. We can therefore posit that relationships are critical to our learning processes and should therefore receive special attention in all our teaching or education processes.

Let us introduce some other voices from the literature though. In her passionate TED talk, Rita Pierson (2005) states that we are convinced of the reasons for bad learning experiences amongst students:

We know why kids don't learn. It's either poverty, low attendance, negative peer influences. We know why. But one of the things that we never discuss or we rarely discuss is the value and importance of human connection, relationships. (p. 1)

In an interview, the politician and educator James Comer (2005) developed an educational process founded on 'positive interpersonal relationships'. He proposed that:

\begin{abstract}
... that's why you have to pay attention to their development, to the relationship that promotes (students') development, and then that makes the children available for learning. ... And so in the process, you build into your social program activities that will bring people together in a respectful way and they come to appreciate each other, and that then makes the school a safe and good place. People feel belonging, they feel respected, their selfesteem goes up as a result of the respect they are given and then you get good relationships. ... But it is a combination of high expectations and good relationships that motivates children to learn. (Comer 2005:1)
\end{abstract}

He goes even further, suggesting that not only relationships in the learning space, but also relationships with the parents and other significant others, facilitate good educational processes.

Pierson (2005) concludes her talk by saying: it's the connection. It's the relationships. And that is what this article wants to echo and hand over to challenge the readers.

\section{Relationship building}

A few examples of approaches to relationship building will be discussed. These approaches are intended to provide suggestions for relationship building which might have a contextual bias. Not all of them will therefore be appropriate for every educational setting.

\section{Sitting in each other's silence as an example of contemplative practice: An invitation to grace}

'Come, let us be quiet for a while. But today I would like to invite you to become still in a very specific manner - come and sit in the silence of the person next to you.'

It is with this invitation that I start all my classes these days and even some of the counselling conversations at the counselling centre where I work. The initial reaction is one of surprise, even scepticism perhaps! And it is also not the easiest practice in which to participate, especially the first time! Most of us may have been invited to become silent 
at some stage perhaps. Sometimes this might have been an invitation to silent prayer, sometimes a more meditative or contemplative practice. But even in these examples, the focus is mostly on personal silence, personal stillness or silence before God. To be 'in the silence of another' is mostly not part of the meditative practice though.

Then why would we consider participating in such a practice in the first place? I use this practice to sensitise participants to the other or otherness. Thus it becomes an exercise in awareness in which we deliberately become mindful of the other in our presence. But then also in a very specific manner: by placing ourselves in the silence of the other, by sitting down in the silence of the other! And this becomes an invitation to grace - sitting down in the grace of the other.

In order to assist participants to this exercise to move into this silence more comfortably - especially earlier on - I suggest two images which might be useful. I suggest that participants might imagine each other to be either shady trees in a hot summer landscape or, in winter time when the former suggestion might appear too cold, considering each other to be a fireplace with the warm glow of the firelight and then to sit down in each other's warmth.

My experience is that this practice has an impact in various ways. For all participants it strengthens the experience of the community of being in each other's presence. Community is therefore promoted by this practice. The interaction amongst participants also takes a different turn - it appears as if relationships of trust are strengthened and even develop much earlier perhaps. The flow of conversation comes more easily from the domain of contingency (or actions, events and reactions) to the domain of meaningfulness (or significance) or even to that which we may describe as the intentional, or then intentionality. This refers to what is meaningful in our lives, our hopes for our lives or the purpose of living (the teleological intention).

Within a narrative paradigm, it is important to get to the implicit justifications in our life narratives (or the Why behind the action). Thus, Michael White (2007) in the first chapter of his book Maps of narrative therapy described a 4-phase process by means of which we can traverse the space from what has happened to why its effect has been significant in our lives. This provides access to an understanding of the intentionality or significance platform which springboards our behaviours or actions. Another way of describing this process, is that it surfaces the 'not yet said', or the 'absent but implicit' in any social process.

What is the origin of the practice of sitting in each other's silence then? This practice is derived from something practiced amongst 'horse whisperers'. At his or her first encounter with a horse, they often just go and sit in the 'silence of the horse'. After a while, the horse will approach the horse whisperer on its own accord to investigate - and this is the start of a relationship of trust between horse and human being!

Thus far I have only received positive feedback about this practice and I am expanding the concept to include an experience of the other as 'thou' in the context of Martin Buber's 'I-it' and 'I-thou' relationships (Buber 1957). This would refer to the sacred space of the relationship or respecting the 'holiness' of the other. It therefore becomes an expansion of the experience of 'sitting in the grace of the other'. This experience of the other as 'thou' acknowledges the dreams, intentions, hopes, passions and expectations of the other, in the same way that I consider my own dreams, intentions, hopes, passions and expectations to be precious and treasure them.

\section{Decentring the lecturer - the lecturer as participant to the learning conversation}

Decentring here refers to a repositioning of the lecturer or teacher from the hub of the knowledge circle or learning circle into the knowledge rim, to become a participatory knowledge conversation partner. This suggests a shift in power relations within the learning process, resulting in a more egalitarian knowledge process. This section will ask the question whether this is possible at all in a practical educational context. I will attempt to illustrate how such decentring initially creates a sense of insecurity and even resistance, only to open up into a participatory pedagogical practice over time. As such, it has the potential to be constructive of relationships and action learning.

Crossman (n.d.) describes the decentred self as follows:

The decentred self is the concept that individual people are not the ultimate source of knowing. In other words, our egos and thinking minds are not at the center of this as autonomous knowers. Instead, what we know exists only in relation to other people, social systems, and the shift in character from one social system to another. (n.p.)

This description illustrates the poststructuralist nature of decentring. Post-structuralism may be understood to refer loosely to a philosophy of moving beyond structures in the epistemological context, equalising all voices involved in the knowledge creation conversation. Relationships and a relational constructionism are also introduced in this description as integral to decentring.

Madigan (2011:165) refers to decentring as 'according priority to the personal stories and to the knowledge and skills' of clients. Michael White's (2011:3) thinking resonates strongly with this where he goes on to allude to an enrichment of the agency story of the client. This not only acknowledges the significance of the client's story, but also contributes to the development of agency. The implications for educational processes may be vast and might range from an acknowledgement of the understanding of the student to inviting more conversation and participation to the learning process. Privileging of understanding is largely avoided 
as conversational space opens up in this practice and all understandings are respected. Students are therefore invited to become associates or partners to the learning process and relationships are strengthened as it occurs.

Decentring practices may include changing the formal lecturing environment into a conversational space, overtly emphasising the importance of participation, introducing seminars rather than lectures, round-table discussions, collaborative pedagogy and process drama.

Asking questions instead of consistently making statements as suggested by Ed Schein (2013:1, 4-5) can facilitate this decentring process even further. These questions should be asked from a position of 'not-knowing', building relationships based on curiosity and interest in the other person, or in this case, the learner.

In training our therapists in the pastoral care centre where I have been working at the time of this article, we replaced formal lecturer-privileged classes with seminar-type discussions and similar participatory and reflective practices. Initially students report experiencing a lack of security and even a certain dissatisfaction with their learning experience. This resistance is soon replaced by stories of empowerment or agency and personal growth though. The decentred approach described above is strongly complemented by the contemplative practice of 'sitting in each others' silence' described above.

\section{Creating safe spaces}

The ability to [create] a safe space at will may well be one of the most vital skills needed to create an ongoing successful relationship. In fact, failure to give this skill the attention and the work it merits may well be the reason one forever fails to achieve the ideal one has envisioned. (Rafanello n.d.)

As Rafanello (n.d.) suggests in the quote above, creating safe spaces may be the most important aspect of relationship building. The following suggestions may be explored in creating such safe spaces:

- A non-judgemental space: A safe space needs to be a non-judgemental space. This needs to be stated upfront as a precondition to dialogue in class and modelled by example. This implies that responses should not be assessed in terms of a reductionist binary categorisation of 'right' or 'wrong', but may for instance rather be discussed for its impact or effect. The practice of externalising may assist us in this regard, when we deliberately distinguish between response and responder and the responder does not become his or her response. Appreciation which is discussed later also plays a part in creating non-judgemental spaces.

- Boundaries: Students should be alerted to the benefit of emotional boundaries and time should be spent on developing processes which might be useful in creating such boundaries. Such boundaries may be the result of negotiated respectful personal spaces. As such, boundaries should be socially constructed by means of a co-construction process. Implicit to this process is shared respectfulness as a prerequisite to relational boundaries. Boundaries may involve the ability to say 'no'. Referring to Rob Bell's (2012) Nooma 020 - 'Shells', saying 'no' follows easier once one has said 'yes'. This 'yes' implies a reflection on values, purpose, and intentionality - which reside in the domain of identity. Therefore some identity work may be required if healthy emotional boundaries are to be set.

- Appreciation: Appreciation forms an integral part of the process of creating safe spaces. It is however important that the appreciation be authentic. Appreciation also does not necessarily mean praise. A more authentic way of expressing appreciation is by indicating how it is meaningful to oneself or what the effect of the contribution is in one's own life - thereby contextualising the appreciation in authentic personal experience rather than in the suggestion of a universal measure of worth. One may easily participate in and contribute to discourses of measurement or 'not measuring up' inviting the student into processes of self-monitoring or even self-questioning which remind of the Panopticon effect described by Foucault (1979) and adapted to the therapeutic conversation by White (1991), who refers to this form of power as self-surveillance or self-regulation according to perceptions of socially acceptable norms. Praise as appreciation can easily position the praisegiver as a person with expert knowledge on that which is praise worthy. Students even become 'conditioned' to that which they experience as being worthy of praise and regulate their learning experience and participation to the learning conversation accordingly. This may result in conforming behaviour rather than a willingness to take risks in the learning environment.

- Agentive space: Following Drewery (2005) we may think of agency as an experience of being a co-author to one's own life narrative. Implicit to this understanding, therefore, is the relational nature of agency. An experience of agency may be enhanced by some of the processes described previously. A safe space may be conducive to an experience of agency, which in turn, may improve the sense of safety, for example. Similarly appreciation could facilitate agency. Agency as understood here does not refer to individual empowerment, but to co-authorship, and co-authorship refers to a skill of co-creating meaningfulness in social contexts.

- Vulnerability: The courage to be vulnerable presents itself as a paradox. Courage and vulnerability are not juxtaposed that often. The courage to be vulnerable, though, is what allows people to open up and approach others without having to guard against being judged or measured. As Brené Brown (2012) puts it in her TED Talk 'Listening to shame': '... if we're going to find our way back to each other, vulnerability is going to be that path.' A safe space will have to take cognisance of this and allow students and other learners to become vulnerable to each other - and make that 'OK'! This reminds one of David 
Whyte's talk previously mentioned in which he mentions hiding behind walls and still wanting to connect or be in relationship (Whyte 2011).

- Make your intention to create a safe space known to all participants

- Lead by example: Illustrate how the boundary of a skill can be tested and also show how you can be safe in attempting something where you have no skill.

- Trust: Too often our understanding of trust is limited to a piggy bank process. This is founded in the discourse that trust should be earned. In a cause and effect process, trustworthy actions should precede trust, much in the way one deposits coins into a piggy bank in order to be able to withdraw from this investment in due course. The risk associated with this approach is that an ample trust investment is not defined and it might result in a position of waiting for the untrustworthy event to occur.

Following Benner (2011:5), the alternative should be to 'lean into trust', which requires a positioning of 'openness and expectant hopefulness'. In other words, trust follows from an intentionality rather than being conditional on behaviour.

In a very informative essay on how to create a safe space within which students would be willing to take academic risks, Smith (2005) suggests that:

... when you build relationships with your students and demonstrate an investment in them, three incredibly positive things happen: You get to know a classroom full of amazing kids, those students become invested in their relationships with you, and as they become more invested in you, they become more invested in the material you teach. Those relationships provide an incredible foundation of trust that allows you to connect emotionally and intellectually with your students, and that connection can produce remarkable results. (n.p.)

\section{Vulnerability as invitation to relationship}

Vulnerability not only is a means to create safe spaces; it is also an invitation to relationship. In her book The gifts of imperfection, Brown (2010:53) states that, contrary to common belief, courage is not synonymous with immunity to criticism. Rather it stems from telling our stories - even if that means that we put ourselves in vulnerable positions. She proceeds to suggest that staying vulnerable is a risk we have to take if we want to experience connection. Rather than always 'putting our best foot forward' and thus ensconcing ourselves in what we might consider to be a comfortable position, authenticity in creating relationships might really only follow from vulnerability - almost in a 'warts and all' presentation of the self.

\section{Leaning into trust versus trust as a piggy bank - the example of the tortoises' picnic}

If trust is considered critical to the formation of relationships, we might be tempted to go about building trust much in the same way that we build a small cash investment - by 'depositing' stories of trustworthy behaviour in our trust piggy bank until trust has been proven.
The joke about three tortoises going on a picnic illustrates this beautifully. They forget the ketchup at home and the youngest is sent back to fetch it. Complaining that they would start the meal without him, he reluctantly leaves. Days afterwards, the remaining two tortoises relinquish hope and accept that he is not returning. Just as they are about to take the first bite, the youngest jumps from behind a bush shouting 'I told you so!'.

As is suggested by the humorous tale above, it may be very difficult to decide when enough trust had been invested as a proof of trustworthiness, and we may resort to a cautious and reserved position of awaiting the next dishonouring of the trust relationship.

A conditional approach to trust building might therefore be risky. As an alternative, it is suggested that 'leaning into trust' as proposed by Benner (2011:5) and discussed above, might rather produce trust as an approach to life rather than trust as a condition to relationship.

\section{Process drama as relationship cradle}

'Composition of action as plot ... depends on the consensual and generative relationships of individuals' (Burns in Hinchman \& Hinchman 2001:176).

According to Wikipedia (2013), Process drama is a method of teaching and learning where both the students and teacher are working in and out of role. Quoting Bolton $(1979,1984,1992)$ and Bolton and Heathcote (1995), this source reports that, as a teaching methodology, process drama developed primarily from the work of Brian Way, Dorothy Heathcote and Gavin Bolton, and through the work of other leading drama practitioners (see Baldwin 1991; Morgan \& Saxton 1987; Neelands \& Goode 2000; O'Neill 1995; O'Toole 1992). It proceeds to describe that process drama in school settings

usually involves the whole class working with the teacher in role in a made up scenario. When they are working in process drama, the students and teachers work together to create an imaginary dramatic world within which issues are considered and problems can be solved. In this world they work together to explore problems and issues such as, 'How do communities deal with change?', 'How do we accept other people into our community?' or themes such as environmental sustainability, betrayal, truth and other ethical and moral issues. (Wikipedia 2013)

Wikipedia (2013) continues to suggest that

sometimes the work may begin as light-hearted, but [that] the teacher [will] always [layer] more dramatic tension and complexity into the work as the teacher is aiming for a pedagogical outcome. [In this way], students learn to think beyond their own points of view and consider multiple perspectives on a topic through playing different roles.

The example provided here is that,

if the issue being discussed is logging a forest, [students] may play the loggers, people who live in the forest community and environmentalists. Playing a range of positions encourages them 
to be able to recast themselves as the 'other' and to consider life from that viewpoint, thereby creating complexity and enabling us to explore multiple dimensions of the topic.

It concludes by stating that process drama does what the character Atticus Finch from the award-winning novel, To kill a mockingbird by Harper Lee (1960), advocates: the ability to work for social justice comes from the ability to understand another perspective - to be able to try on someone else's shoes and walk around in them for a while. Process drama allows us to 'try on' other people's shoes, to walk the paths they tread and to see how the world looks from their point of view.

Process drama assists in building relationships in that it involves both teacher and students to co-create meaning in a relational process. In assuming different roles, a certain decentring of power positions is invariably facilitated. All the participants are cast in third party roles, which creates an experience of an egalitarian and uncolonised (see Drewery 2005) meaning space.

\section{The culture of the learning institution as the 'hidden curriculum'}

Ignelzi (2000:8) introduces Kegan's (1994) concept of 'hidden curricula'. Kegan refers to so-called 'Order 4' meaningmakers who 'construct their sense of meaning and the self such that self-authorship is the key feature'. This reminds of the way in which Drewery (2005) describes agency, which she is quick to note, is a relational process. Self-authorship should therefore be considered to be a dialogical and hence relational identity project.

Kegan suggests that a certain 'hidden curriculum' is demanded from such 'Order 4' meaning-makers. These 'demands on the mind' involve that such an 'Order 4' student or meaning-maker:

- Exercise critical thinking.

- Be a self-directed learner (take initiative; set our own goals and standards; use experts, institutions, and other resources to pursue these goals; take responsibility for our direction and productivity in learning).

- See ourselves as the co-creators of the culture (rather than only shaped by culture).

- Read actively (rather than only receptively) with our own purpose in mind.

- Write to ourselves, and bring our teachers into our selfreflection (rather than write mainly to our teachers and for our teachers).

- Take charge of the concepts and theories of a course or discipline, marshalling on behalf of our independently chosen topic its internal procedures for formulating and validating knowledge (Kegan 1994:303).

Although the tone of these demands seem to be individualistic, closer scrutiny reveals that they are supportive and constructive of action learning, and that a distinct element of participation becomes evident. Reflecting and participating in this way will involve the student actively and therefore be facilitating of relationship building.

\section{Handing over the conversation}

In this article, the author endeavoured to indicate the critical role of relationship in the educational process. The relational nature of humans as meaning-seekers was used as the foundation for the proposal. Learning was then shown to be a meaning-making process. Thus the relational nature of learning became evident and positioned relationship as critical to the training and education discourse. Some relationship-building technologies have been suggested and these can still be enriched with more practical ways of being in relationship.

This article has not spent any time on relational ethics - a topic which deserves some reflection when the critical role of relationship in education and training is discussed. Furthermore, participatory relational practice should be explored and developed further in subsequent research.

\section{Acknowledgements Competing interests}

The author declares that he has no financial or personal relationship(s) that may have inappropriately influenced him in writing this article.

\section{References}

Abram, D., 1997, The spell of the sensuous: Perception and language in a more-than human world, Vintage Books, New York, NY.

Baldwin, P., 1991, Stimulating drama: Cross curricular approaches to drama in the primary school, Norwich County Council, Norwich.

Bell, R., 2012, 'Nooma 020: Shells', viewed 27 February 2015, from https://www. youtube.com/watch?v=bKTHJOTwnto\&spfreload $=10$

Benner, D.G., 2011, Soulful spirituality, Brazos Press, Grand Rapids, MI.

Bolton, G.M., 1979, Towards a theory of drama in education, Longman, London.

Bolton, G.M., 1984, Drama as education, Longman, London.

Bolton, G.M., 1992, New perspectives on classroom drama, Nelson Thornes Ltd., London.

Bolton, G.M. \& Heathcote, D., 1995, Drama for learning: Dorothy Heathcote's mantle of the expert approach to education, Heinemann Drama, Portsmouth. (Dimensions of Drama Series).

Brown, B., 2010, The gifts of imperfection, Center City, Hazelden.

Brown, B., 2012, 'Listening to shame', viewed 27 February 2015, from http://www.ted. com/talks/brene_brown_listening_to_shame

Bruner, E.M. 1986, 'Experience and its expressions', in VW. Turner \& E.M. Bruner (eds.), The anthropology of experience, p. 7, University of Illinois Press, Chicago, IL. Bruner, J., 1990, Acts of meaning, Harvard Press, Cambridge.

Buber, M., 1957, I and thou, transl. R.G. Smith, Continuum, London.

Carey, M. \& Russell, S., 2003, 'Re-authoring: Some answers to commonly asked questions', International Journal of Narrative Therapy and Community Work 3 , $60-71$.

Comer, J., 2005, 'Interview with Dr. James Comer, founder Comer School Development Program and professor of Child Psychiatry, Yale University', viewed 16 April 2014 from http://www.pbs.org/makingschoolswork/sbs/csp/jamescomer.html

Courtenay, B.C., Merriam, S.B. \& Reeves, P.M., 1998, 'The centrality of meaningmaking in transformational learning: How HIV-positive adults make sense of their lives', Adult Education Quarterly 48, 65-84. http://dx.doi. org/10.1177/074171369804800203

Crossman, A., n.d., 'Decentered self', viewed 26 March 2014, from http://sociology. about.com/od/D_Index/g/Decentered-self.htm

Drewery, W., 2005, 'Why we should watch what we say: Position calls, everyday speech and the production of relational subjectivity', Theory \& Psychology 15 305-324. http://dx.doi.org/10.1177/0959354305053217

Foucault, M., 1979, Discipline and punish: The birth of the prison, Peregrine Books, Middlesex. 
Gergen, K.J., 2009, Relational being: Beyond self and community, Oxford University Press, New York, NY

Grentz, S., 2006, 'The social God and the relational self: Toward a theology of the Imago Dei in the postmodern context', in R. Lints, M.S. Hornton \& M.R. Talbot (eds.), Personal identity in theological context, pp. 70-93, Wm B Eerdmans Publishing Co., Grand Rapids, MI.

Hinchman, L.P. \& Hinchman, S.K., 2001, Memory, identity, community - The idea of narrative in the Human Sciences, SUNY Press, New York, NY.

Ignelzi, M., 2000, 'Meaning-making in the learning and teaching process', New Directions for Teaching and Learning 82, 5-14. http://dx.doi.org/10.1002/ti.8201

Kegan, R., 1982, The evolving self: Problem and process in human development, Harvard University Press, Cambridge.

Kegan, R., 1994, In over our heads: The mental demands of modern life, Harvard University Press, Cambridge.

Lee, H., 1960, To kill a mockingbird, Harper Collins Publishers, New York, NY.

Madigan, S., 2011, Narrative Therapy, American Psychological Association, Washington, DC.

Moore, T., 1994, Soul mates: Honoring the mysteries of love and relationship, Harper Perennial, New York, NY.

Morgan, N. \& Saxton, J., 1987, Teaching drama: A mind of many wonders, Trans Atlantic Publications, Cheltenham.

Neelands, J. \& Goode, T., 2000, Structuring drama work: A handbook of available forms in theatre and drama, Cambridge University Press, Cambridge.

O'Neill, C., 1995, Drama worlds: A framework for process drama, Heinemann Drama, Portsmouth. (Dimensions of Drama Series).

O'Toole, J., 1992, The process of drama: Negotiating art and meaning, Routledge, Abingdon, OX. http://dx.doi.org/10.4324/9780203359617
Pierson, R., 2005, 'Every kid needs a champion', viewed 16 April 2014, from http:// www.ted.com/talks/rita_pierson_every_kid_needs_a_champion

Rafanello, J.M., n.d., 'Creating a safe space: A vital skill', viewed n.d., from http://www. wonderworldonline.com/creating-a-safe-space

Sacks, J., 2000, A politics of hope, Vintage, London.

Savage-Rumbaugh, S., 2004, 'The gentle genius of the bonobos', viewed 27 February 2015, from http://www.ted.com

Schein, E.H., 2013, Humble inquiry - The gentle art of asking instead of telling, BerrettKoehler Publishers Inc., San Francisco, CA.

Smith, K.J., 2005, 'Creating a safe space for students to take academic risks', viewed 05 April 2014, from http://www.learnnc.org/lp/editions/firstyear/258

Wessels, F., 2010, 'Narrative reflections on a life that matters', PhD thesis, Dept Practical Theology, University of Pretoria.

Wessels, F., 2014, Francois Wessels Blog, available from http://www.kune.co.za/ blog/Post/182/The-teacher-who-is-indeed-wise-does-not-bid-you-to-enter-the house-of-his-wisdom-but-rather-leads-you-to-the-threshold-of-your-mind-KhalilGibran?

Wikipedia, 2013, 'Process drama', viewed 14 April 2014, from http://en.wikipedia. org/wiki/Process_drama

White, M., 1991, 'Deconstruction and therapy', Dulwich Centre Newsletter 3, 21-40.

White, M., 2007, Maps of narrative therapy, Dulwich Centre, Adelaide.

White, M., 2011, Narrative practice - Continuing the conversations, W.W. Norton \& Company, New York, NY.

Whyte, D., 2011, 'The conversational nature of reality: Life at the frontier', viewed 09 March 2014, from http://www.studioriley.com/learning-from-davit-whyte-theconversational-nature-of-reality-tedx-puget-sound/ 